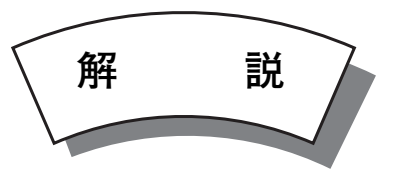

\title{
モバイル機器用ダイレクトメタノール形燃料電池
}

\section{Direct Methanol Fuel Cells for Mobile Applications}

Key Words: DMFC, PC, Battery, Catalyst, LIB

\section{1. 緒 言}

ノート PC、携帯電話、携帯オーディオプレーヤー、携帯 ゲーム機、小型プロジェクターなどモバイル機器の高機能 化はとどまることをしらず、これらを長時間使用したいと いうニーズはますます増えている。省電力化が進んできて はいるが、ニーズに応えるためには搭載する電源容量の増 大が必要である。現在、モバイル機器用の二次電源として はリチウムバッテリ（LIB）が広く使用されている。LIBの 容量を飛躍的に増大させることは正極材料、負極材料、電 解液等の新材料の開発が必要であり、安全性の確保も含め て技術的な困難性が高い。

メタノール $\left(\mathrm{CH}_{3} \mathrm{OH}\right)$ を燃料として、改質により水素を取 り出すことなく、直接電気化学的に発電するダイレクトメ タノール形燃料電池（DMFC：Direct Methanol Fuel Cell）は メタノールのエネルギ密度が高く機器の小型化に適してい ること、液体然料として扱いやすく持ち運びが容易である こと、燃料を継ぎ足して継続的に機器の使用が可能である ことなどからモバイル機器用の新しい電源として注目を集 めている ${ }^{1)}$

本稿では DMFC の原理と特徵、東芝の開発状況について 紹介し、他機関の DMFC 開発状況、DMFC 以外の方式の状 況についても簡単に紹介する ${ }^{2,3)}$ 。

\section{DMFC の原理}

DMFCの原理を図 1 に示した。DMFCの発電部は膜電 極複合体（MEA: Membrane Electrode Assembly）と呼ばれ、 電解質膜とその両側の触媒層、ガス拡散電極（GDL：Gas Diffusion Layer) からなる。アノード触媒（通常は PtRu 合 金触媒) 上ではメタノール $\left(\mathrm{CH}_{3} \mathrm{OH}\right)$ と水 $\left(\mathrm{H}_{2} \mathrm{O}\right)$ が反応して 二酸化炭素 $\left(\mathrm{CO}_{2}\right)$ とプロトン $\left(\mathrm{H}^{+}\right)$と電子 $(\mathrm{e}-)$ ができる（式 1）。プロトンは電解質膜を通過してカソード触媒（通常は $\mathrm{Pt})$ 上で酸素 $\left(\mathrm{O}_{2}\right)$ と外部回路を流れた電子と反応し、水 が生成する (式 2)。全体としては 1 分子のメタノールと 1.5

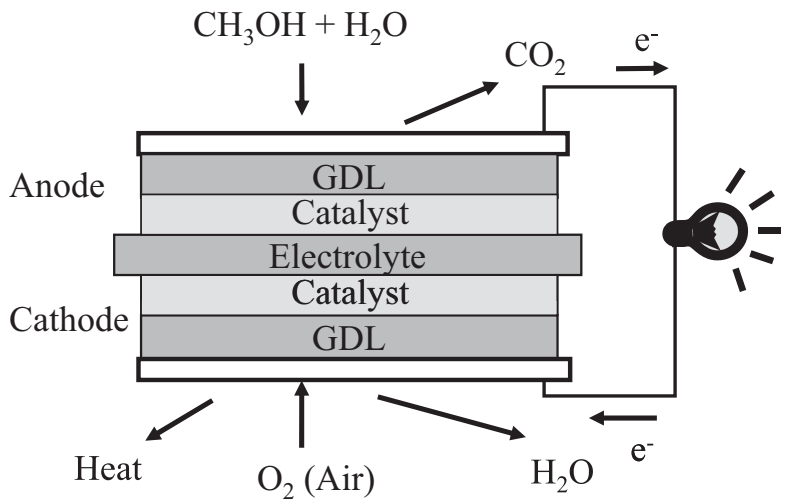

Fig.1 Electric power generation principle of DMFC

分子の酸素から 1 分子の二酸化炭素と 2 分子の水が生成す る（式 3）。DMFC はメタノールと酸素を供給し、水と二酸 化炭素を排出し、熱も発生する。

$\mathrm{CH}_{3} \mathrm{OH}+\mathrm{H}_{2} \mathrm{O} \rightarrow \mathrm{CO}_{2}+6 \mathrm{H}^{+}+6 \mathrm{e}-$

$6 \mathrm{H}^{+}+6 \mathrm{e}^{-}+3 / 2 \mathrm{O}_{2} \rightarrow 3 \mathrm{H}_{2} \mathrm{O}$

$\mathrm{CH}_{3} \mathrm{OH}+3 / 2 \mathrm{O}_{2} \rightarrow \mathrm{CO}_{2}+2 \mathrm{H}_{2} \mathrm{O}$

電解質膜としては通常固体高分子電解質膜が用いられる が、液体電解質なども用いることができる。

DMFC はそのシステム構成からアクティッブ型とパッ シブ型に大きく分かれる。図 2 にその概略を示した。アク ティッブ型はセルを何層も重ねたスタックを有し、補器を 用いた機構（燃料供給、燃料循環、空気供給、水回収、冷 却等）で運転制御を行う。一方パッシブ型は機構を用いず、 燃料も空気も自然対流や濃度拡散等で行う方式である。ア クティッブ型は多少大きくなるが高出力が得られ、ノート PC などの電源として、また出力は小さいがパッシブ型は小 型化に適し、携帯電話などの電源に向いている。アクティッ ブとパッシブ型の中間の構成も考えられ、用途によりシス

*株式会社東芝研究開発センター（－212-8582 川崎市幸区小向東芝町 1)

Corporate Research \& Development Center, Toshiba Crporation (1 Komukai-Toshiba-cho, Saiwai-ku, Kawasaki, 212-8582, Japan) 


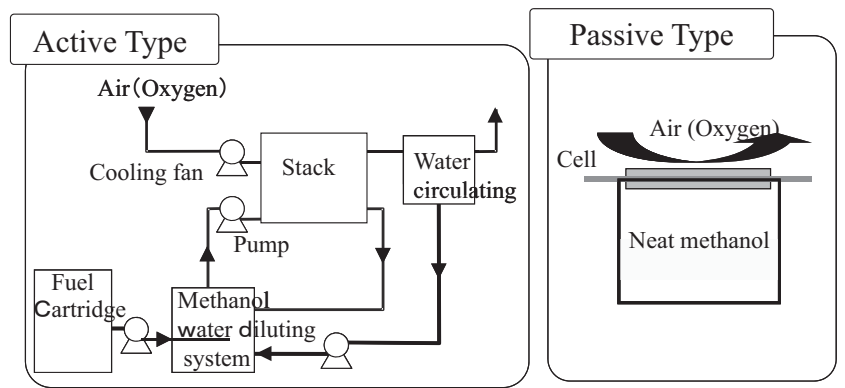

Fig.2 System difference between active and passive type DMFCs

\section{テム構成は異なる。}

DMFC は機器の初期駆動時など瞬間的に大電流が必要な 場合には小さな容量の LIB やコンデンサなどと組み合わせ たハイブリッドシステムも用いられる。

\section{DMFC の特徵と課題}

モバイル機器用電源として DMFC の特徽は、水素と比べ てメタノールの理論エネルギ密度が $6.1 \mathrm{kWh} / \mathrm{kg}$ と極めて高 いことである（図 3）。また燃料を継ぎ足せば充電すること なしにすぐに発電できる。LIBの充電には充電器と AC 電 源（コンセント）が必要であるが、DMFC の場合は燃料を 携帯すれば場所の制約なくどこでも充填が可能である。

DMFC の理論電圧は $1.2 \mathrm{~V}$ であるが触媒反応の過電圧、 原料の拡散抵抗、電気抵抗、燃料メ夕ノールが反応せずに アノードからカソードへ透過・酸化されるメタノールク ロスオーバー等のために実際の電圧は半分以下に低下する (図 11 参照)。このため、電圧を所望の值まで上げるため にはセルを積層したり、DC-DC（直流一直流）コンバーター で昇圧して用いる。

DMFC のエネルギ変換効率は通常 $20 \sim 30 \%$ であり、燃 料のエネルギ密度は $1.2 \sim 1.8 \mathrm{kWh} / \mathrm{kg}$ 程度になる。LIB は エネルギ密度が高い円筒形でも $0.2 \mathrm{kWh} / \mathrm{kg}$ 程度であり、そ れと比較するとかなり大きい。

LIB は蓄積されるエネルギ量が重量とほぼ比例するのに 対し、DMFC は発電部が必要であるため図 4 で模式的に示 すように少ない重量領域では LIB と比較するとエネルギ密 度は小さくなる。大きな重量では DMFCの方がエネルギ密 度は大きくなる。両者の交差するポイントが重要であり、 DMFC を実用化するためにはその交差ポイントをできるだ け低い重量のところに持ってくることが必要である。その ためには所望の出力を与える発電部をできるだけ小さく軽 くすることである。

発電部を小さくすると放熱が困難になるため、冷却効率 の改善や発電効率を上げる必要がある。発電効率を上げる には、活性の高い触媒、抵抗の少ない膜、メタノールクロ スオーバーを小さくすることが有効であり、材料開発が必 要である。

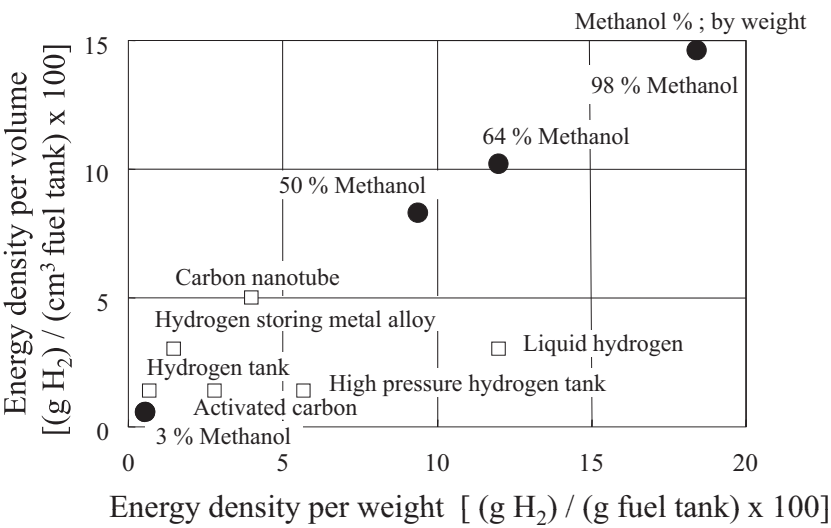

Fig.3 Energy capacity of methanol and hydrogen (including containers)

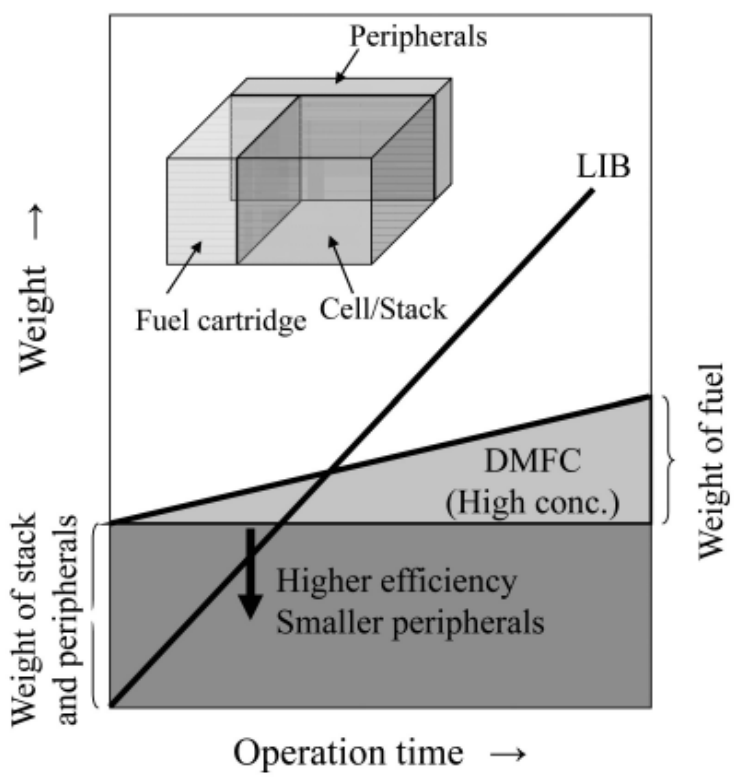

Fig.4 Relations between weight and operation time for LIB and for DMFC

電解質膜には通常フッ素系のプロトン伝導性膜が用いら れているが、メタノールクロスオーバーが高いことが課題 である。これを改善するために炭化水素系のプロトン伝導 性膜や、無機混合膜等が開発されているが、プロトン伝導 性が一般的に低くなり、抵抗が上がってしまうことが課題 である ${ }^{4)}$

小型化のためには、ポンプ等の補器を小さくすることも 必要である。補器の小型化は補器の駆動に必要な電力を抑 え、発電効率を上げるにも有効である。

また燃料としてできるだけ高濃度のメタノールを使用す ることが、機器全体の小型軽量化に必要である。

DMFC の技術的な課題としては、寿命や安全性確保も 必要である。寿命に関しては触媒粒子の増大による活性表 面積の減少、触媒金属の溶け出し、カソードでの水詰まり 


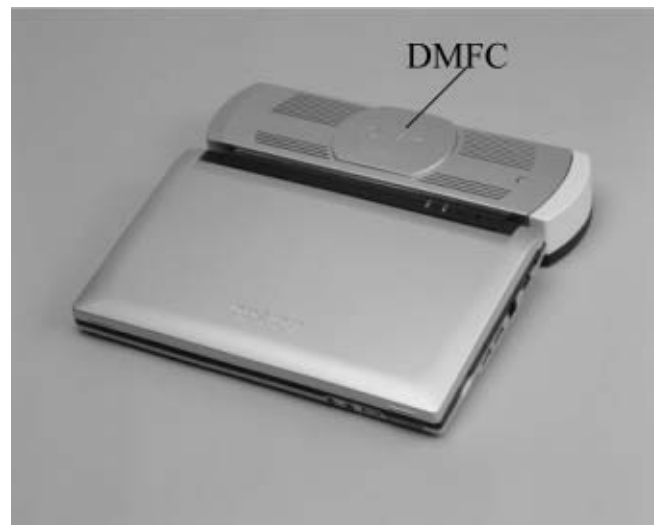

Fig. 5 World first direct-coupled DMFC to notebook PC

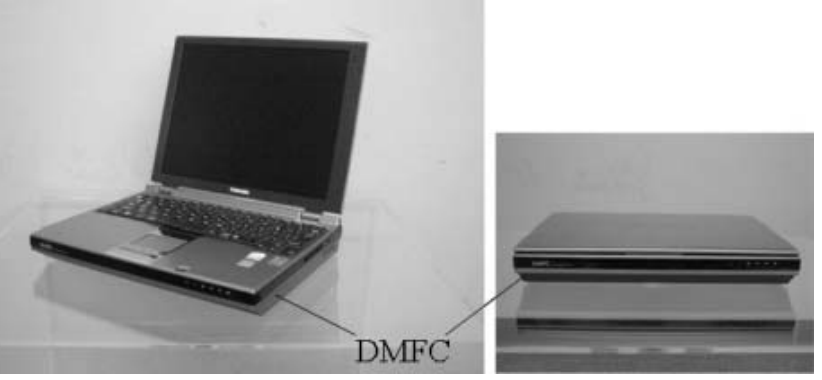

Fig.6 DMFC inside notebook PC

による酸素供給不足、電解質膜の劣化、膜はがれによる抵 抗増大等があり、これらの抑制が必要である。国際電気標 準会議（IEC: International Electrotechnical Commission） で DMFC 機器に対する種々の安全基準が発効見込みであり、 それらを満たすことが必要である ${ }^{5}$ 。

実用化に対しての大きな課題はコストである。モバイル 用機器では電源にかけられるコストには制限がある。量産 化により一般に部材コストは下げられるが、当初はLIBに 比べて高くなると予想され、DMFCのメリットがどこまで ユーザーに認められるかが鍵となる。現状 DMFCでは水素 を燃料とする固体高分子形燃料電池 PEFC と比較すると白 金触媒を単位面積当り一桁ほど多量に用いている。これは メ夕ノールの反応性が低いことに由来している。白金触媒 は量産化によるコスト低減は難しく、省白金化が可能な触 媒開発が必要である。一方、白金自体が無くなるわけでは ないので、回収が可能であり、リサイクルでは量産効果が 期待できる。

最近、高価な白金を用いないカーボンアロイ ${ }^{6)}$ や酸化物 系 ${ }^{7)}$ の新しい触媒開発が盛んに行われている。現状では PEFCのカソード触媒を主なターゲットとしているが、そ の成果が将来 DMFCにも応用されることが期待される。

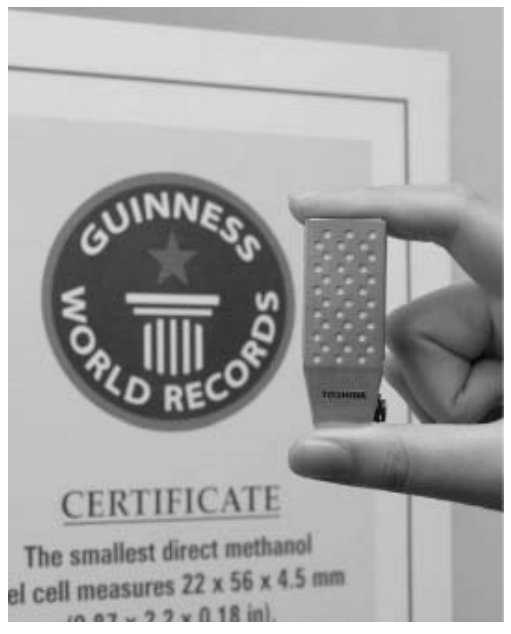

Fig.7 World smallest DMFC certified by Guinness World Record

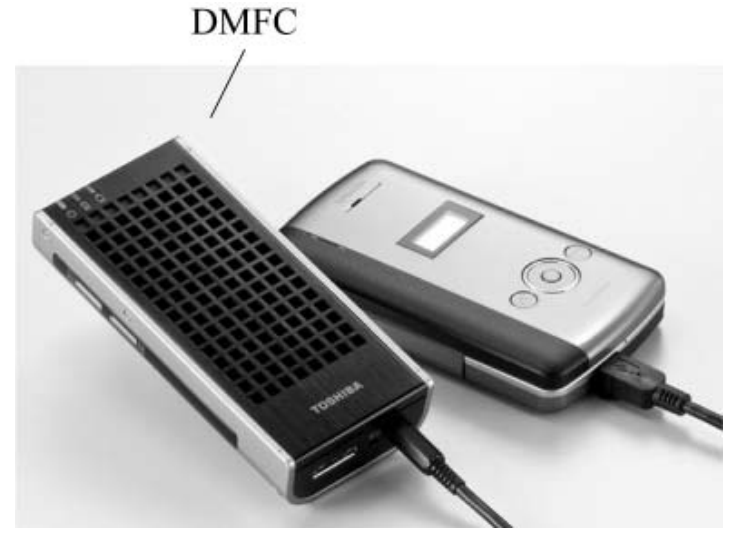

Fig.8 Battery charger for mobile phone

\section{4. 東芝の開発状況}

当社ではノート PC 用（アクティッブ型）とより小型 の携帯機器用 (パッシブ型) の DMFC の開発を進めてい る。2002 年には PDA 向けのアクティッブ型 DMFCを開発。 2003 年には図 5 で示した小型ノートPCの LIB ポートに直 接接続できるプロト機を試作し、2006 年にはノート PCに ドッキングするタイプで、より長時間駆動できるプロト機 を試作した。図 6 は 2007 年に試作したノート PC一体型の 試作機である。ここではナノ構造制御により高出力な MEA を開発し、さらに、燃料となるメタノールと水、また発電 時に排出される水と二酸化炭素の流れ制御を工夫すること により、従来必要とされた補器を一部省略して小型化した。

パッシブ型に関しては、サイズが 22 (幅) $\times 56$ (長さ) $\times 4.6$ (厚み) $\mathrm{mm}$ 、重さ $8.5 \mathrm{~g}$ の DMFCを 2005 年に試作し、2006 年のギネスブックに世界最小と登録された（図 7)。図 8 は サイズが 55 (幅) $\times 120$ (長さ) $\times 25$ (厚み) $\mathrm{mm}$ の携帯電 話用の充電器である。一回の燃料充填で約 2 回、携帯電話 
を充電できる。最近では 2008 年の Mobile World Congress でDMFCを搭載して薄さ $17.5 \mathrm{~mm}$ を実現した携帯電話試 作機を展示した。LIB とのハイブリッドであり、DMFC は LIB の充電に用いられる。間欠的に使用、適宜然料供給す ることによりコンセントからの充電無しに連続的に使用す ることが可能である（図 9）。この場合には DMFC の出力 は常に一定である。また 2009 年の Mobile World Congress ではスマートフォン背面に取り付け可能な DMFC 試作機を 展示した（図 10）。パッシブ型では純メタノールを燃料と して使用できる MEAを開発し、小型化を実現した。

パッシブ型の小型携帯機器の燃料供給には図 9 で示す共 通のカートリッジ（容器専用メーカーとの共同開発試作品） を用いることができる。このカートリッジは内容量が $50 \mathrm{cc}$ で安全性規格に適合させるために、材料選定や構造の設計、 強度の確保、液漏孔対策、誤使用対策などを施している。 機器側とカートリッジ側の接合部（カップラ）の標準化に より、複数の機器に対して一本のカートリッジで然料補給 が可能となり、モバイル環境での利便性が増すことが期待 できる。

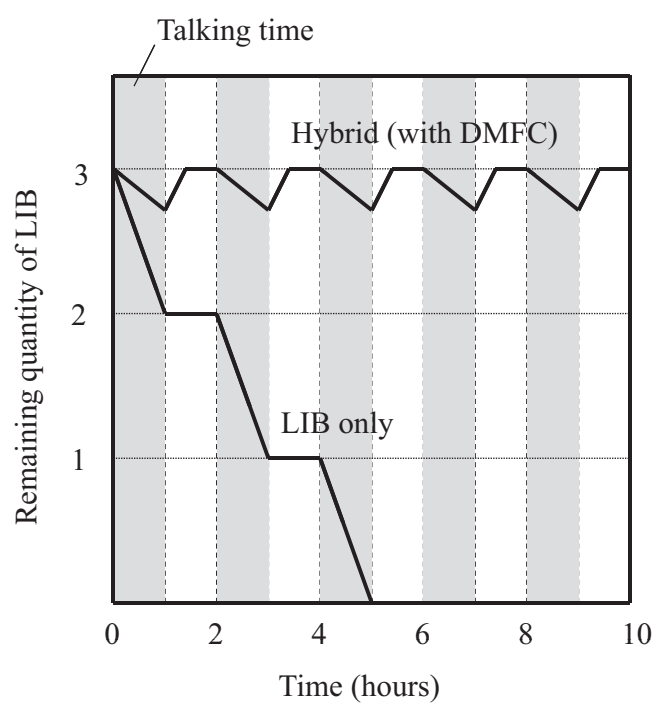

Fig.9 Schematic explanation of LIB only vs. Hybrid (with DMFC)

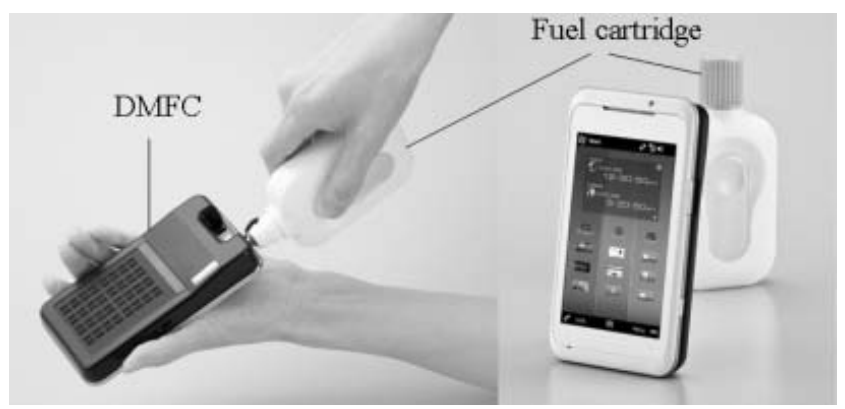

Fig.10 DMFC for smart phone and fuel cartridge
上記システム・機器開発と並行して材料開発も進めてい る。図 11 に開発した触媒材料の一例を示した。PtFe $(\mathrm{N})$ カソード触媒はX線光電子分光（XPS : X-ray Photoelectron Spectroscopy）から Pt は表面に Fe は内部に多く存在し、Pt の触媒作用を効率的に利用できる。 $\mathrm{N}$ は電子的に触媒活性 向上に寄与していると考えられる ${ }^{8)}$ 。図 12 に示したカーボ ンナノファイバー (CNF: Carbon Nano Fiber) 担持体は直径 3 $\mathrm{nm}$ ほどの Pt 触媒粒子を密にかつ均一に分散担持すること ができ、従来の粒子状カーボン担持体（Valcan XC）と比較 してアクティッブ DMFC の出力電圧が向上した ${ }^{9)}$ 。低空気 流量側で差が大きく CNFによる嵪高い構造が効いていると 思われる。

\section{5. 他機関の DMFC 開発状況}

モバイル機器用の DMFC は当社を始め、国内外の電機 メーカーを中心に開発が行われている。最近の動きとして は、2008 年 5 月に開催された Small Fuel Cell では Samsung

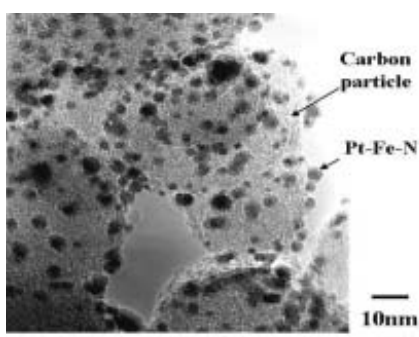

Pt rich surface
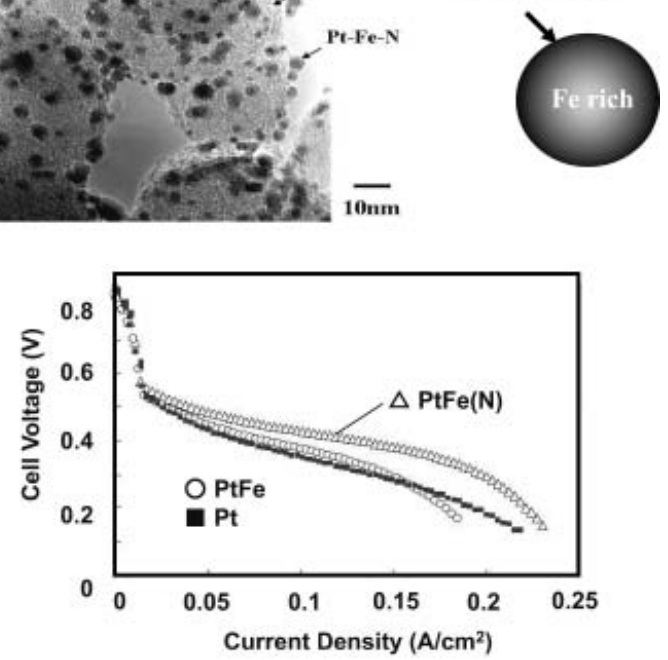

Fig.11 PtFe (N) cathode catalyst and I-V characteristic

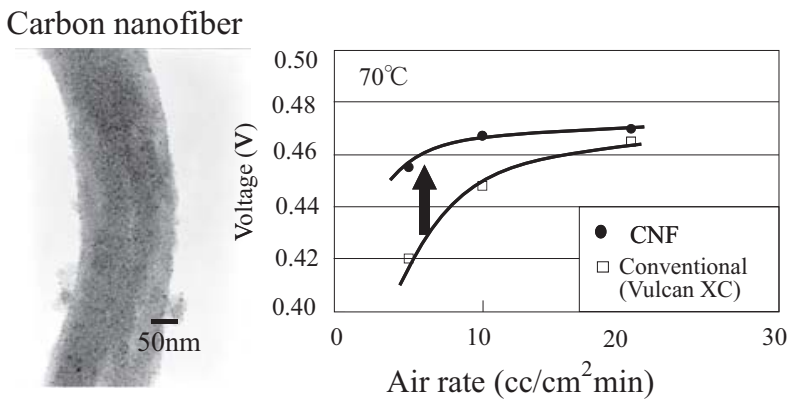

Fig.12 Carbon nanofiber support 
社が PC 用アクティッブ型試作機で各種安定性試験 ${ }^{10)}$ 、ソ ニー社が独自のフラーレン電解質を用いたパッシブ型試作

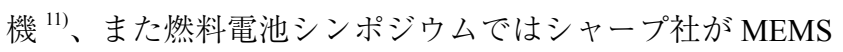
技術を用いてパッシブ型小型スタック ${ }^{12)}$ を発表、10月の水 素エネルギー先端技術展に Panasonic 社がアクティッブタ イプのノート PC 用 LIB サイズと充電器を展示した。2009 年 2 月の FC Expo では NEC 社がポータブル充電器、ソニー 社からインテリア型充電器、スピーカーが展示された。各 社とも小型化や長寿命化、安全性確保、低コスト化を目指 した開発が精力的に行われている。

\section{6. 他の方式によるモバイル機器用燃料電池}

ボロハイドライド $\left(\mathrm{NaBH}_{4}\right)$ を直接燃料とする燃料電池 が開発されており ${ }^{13)}$ 、使い切りタイプの小型充電器が米 Medis Technologies 社から販売されている。アルカリ溶液 を用い、非白金触媒を用い、低コストを実現している。繰 り返し使うタイプも開発中であるが燃料の取り扱いや信頼 性・寿命等が課題である。

水素を発生させて PEFCにより発電するタイプが開発さ れている。日立マクセル社は水とアルミナノ粒子から、ア クアフェアリー社も同様と考えられる方法から水素を得て いる ${ }^{14)}$ 。発電部は小型で高出力が得られる。発熱反応であ る水素発生をいかに制御するかが課題である。メタノール やボロハイドライドから改質により水素を取り出す方式も 開発されている。改質器の小型化や信頼性が課題である。

白金触媒を用いないでエタノールを直接燃料に用いる方 式をイタリアActa 社が開発している。低コストが期待でき るが、アルカリ型であり空気中の二酸化炭素の影響など信 頼性・寿命が課題である。

その他、ギ酸やヒドラジンを直接燃料とする方式が開発 されている。出力は高いが然料の取り扱い等が課題である。

\section{7. 結語}

DMFC 実用化のためにはメタノールを燃料に用いること から生じる規制をクリアすることが必要である。航空機持 込みについては国際民間航空機関 (ICAO: International Civil Aviation Organization) で 2007 年 1 月には DMFC 機器の機 内持ち込みが認められ、国内規制も改正されている。また IECでは燃料やカートリッジに関する標準化も行われてい
る。

DMFC は運転により原理的に $\mathrm{CO}_{2}$ が発生するが、 $\mathrm{CO}_{2}$ 排 出をさらに少なくすることがエコの観点からは望ましい。 運転時の $\mathrm{CO}_{2}$ 発生を低減するには効率を高めることが有 効である。燃料であるメタノールは現在、天然ガスなどの 化石資源を原料に合成されているが、木材などの非食物性 バイオマスを原料に用いて大量に合成することが可能であ り、プラント開発が行われている ${ }^{15)}$ 。また、将来は原子力 や太陽光から製造する水素で $\mathrm{CO}_{2}$ を還元してメタノールを 製造する研究が行われ ${ }^{16)}$ 、最近はプラント開発が行われて いる。

モバイル機器用の新たな電源として世界中の人が DMFC の利便性を享受する日が来ることを期待したい。

\section{引用文献}

1) “次世代電池 2007/2008”、日経 BP 社、東京、2007.

2) 上野文雄 : 電気評論、10 (2005) 27-30.

3) 森 寧: 東芝レビュー、62 (2007) 44-47.

4) V. Neburchilov, J. Martin, H. Wang ., and J. Zhang : Journal of Power Sources 169 (2007) 221-238.

5) 井原卓郎：電機、1(2008)35-38.

6) J. Ozaki, N. Kimura, T. Anahara, and A. Oya: Carbon 45 (9) (2007) 1847-53.

7) A. Ishihara, S. Doi, Y. Liu, S. Mitsushima, N. Kamiya, and K. Ota: Mater. Sci. Forum 539-543, pt.2 : (2007) 1379-84.

8) W. Mei and Y. Nakano: Prepr. Pap.-Am. Chem. Soc., Div. Fuel Chem.,, 51 (2006) 124-125.

9) W. Mei, Y. Nakano, S. Suenaga, M. Yonetsu, Y. Akasaka, H. Oozu, and Y. Goto: Prepr. Pap.-Am. Chem. Soc., Div. Fuel Chem., 50 (2005) $39-40$.

10) I. Song, H. Cho, H. Hwan Choi and H. Chang: Small Fuel Cells 2008.

11) S. Goto and T. Senoo : Small Fuel Cells 2008.

12) 藤田敏之、吉江智寿、山里久雄、柿本誠三 : 第 15 回燃料電池 シンポジウム講演予稿集、(2008) 109-110.

13) B.H. Liu, and Z.P. Li: Journal of Power Sources 187 (2009) 291-297

14) 武松 武裕：Wedge, March (2009) 78-80

15) 中谷浩己、石井弘実、福井和司、西村幸治、武野計二、松本慎治: 三菱重工技報、2 (2005) 130-133.

16) M. Saito, M.Takeuchi, T. Watanabe, J. Toyir, S. Luo, and J. Wu: Energy Convers. Mgmt, 38 (1997) S403. 